\title{
Commentary: Extending into zone 0 with a little help
}

\author{
Abe DeAnda, Jr, MD, ${ }^{a}$ and Leora B. Balsam, $\mathrm{MD}^{\mathrm{b}}$
}

\author{
From the ${ }^{\mathrm{a}}$ Division of Cardiovascular and Thoracic Surgery, UTMB-Galveston, Galveston, Tex; and ${ }^{\mathrm{b}}$ Division of \\ Cardiac Surgery, UMass Memorial Medical Center, Worcester, Mass. \\ Disclosures: Authors have nothing to disclose with regard to commercial support. \\ Received for publication Jan 7, 2019; accepted for publication Jan 8, 2019; available ahead of print Feb 13, 2019. \\ Address for reprints: Abe DeAnda, Jr, MD, Division of Cardiothoracic Surgery, UTMB-Galveston, 301 Univer- \\ sity Blvd, Galveston, TX 77551 (E-mail: abdeanda@utmb.edu). \\ J Thorac Cardiovasc Surg 2019;157:309-10 \\ $0022-5223 / \$ 36.00$ \\ Copyright (c) 2019 by The American Association for Thoracic Surgery \\ https://doi.org/10.1016/j.jtcvs.2019.01.024
}

In this issue of the Journal, Lou and colleagues ${ }^{1}$ present a case report of an acute retrograde type A aortic dissection (rTAAD) that originated from a presumably subacute type $\mathrm{B}$ aortic dissection. ${ }^{1}$ A complicating factor in this scenario was that the patient's religious beliefs precluded him from accepting blood or blood products as a potential consequence of open surgery. The surgeons proceeded with an alternative approach comprised of a staged hybrid repair with debranching of the great vessels, followed a few days later by a zone 0 thoracic endovascular aortic repair supplemented with a chimney graft from the innominate artery. This unique application of the chimney technique was successfully completed, and at 3 months the patient was apparently alive and well with thrombosis of the false lumen.

Acute rTAADs may arise de novo or as a complication of thoracic endovascular aortic repair. Data from the International Registry of Acute Aortic Dissection (IRAD) documented an overall incidence of $7 \%$ in all acute dissections, ${ }^{2}$ similar to the $9 \%$ incidence seen by Kim and colleagues. ${ }^{3}$ The IRAD data are a little confusing, in that a different IRAD study from the same period notes an incidence of $16.5 \%$; however, this was in isolated type B dissections. ${ }^{4}$ Early mortality was lower among patients in whom the rTAAD was limited to the arch than among those in whom the dissection extended into the ascending aorta, although this difference did not achieve statistical significance $(8.6 \%$ vs $18.6 \% ; P=.14)$. In addition, mortalities for open surgical repair $(18.2 \%)$, medical management $(9.1 \%)$, and endovascular repair $(13.6 \%)$ did not differ significantly, with the caveat that the presentation, extent of disease, and degree of false-lumen thrombosis differed among the groups and most likely guided the therapeutic options. There was a difference in clinical presentation seen between zone 0 and zone 1 or 2 rTAAD, with more frequent pericardial effusion $(35.9 \%$ vs $3.6 \%, P<.0001)$, tamponade $(9.8 \%$ vs $0 \% ; P=.03)$, and aortic insufficiency $(27.5 \%$ vs $9.4 \% ; P=.02) .^{2}$ It is not apparent that this patient had any of these issues.

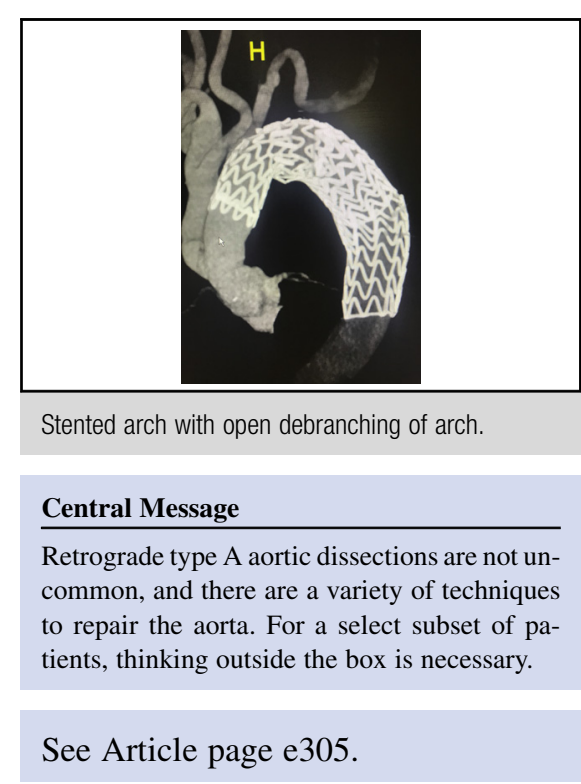

Open repair of type A dissections ${ }^{5,6}$ and staged approaches for ruptured type $\mathrm{B}$ dissections ${ }^{7}$ have been described for Jehovah's Witnesses. There are other options for the clinical scenario described, including on- or offpump open arch debranching with a trifurcated graft followed by thoracic endovascular aortic repair ${ }^{8}$ or medical management. Conservative management might have been sufficient for this patient given his presentation and the subacute nature of the rTAAD. Patients with chronic type A dissections seem to do better than those with acute type A dissections, and those with rTAADs better than those with classic type A dissections, and this patient thus may have been on track to survive without intervention. As is frequently experienced in surgery, however, we just do not know, nor do we have the benefit of extensive experience with these particular cases to determine a perfect algorithm. This hybrid approach may not become a standard of care, but it is a well-described, justified, and thoughtful approach to the problem at hand.

\section{References}

1. Lou X, Jordan WD Jr, Leshnower BG. Chimney endovascular technique for acute retrograde type A dissection in a Jehovah's Witness. J Thorac Cardiovasc Surg. 2019;157:e305-7.

2. Nauta FJ, Kim JB, Patel HJ, Peterson MD, Eckstein HH, Khoynezhad A, et al Early outcomes of acute retrograde dissection from the International Registry of Acute Aortic Dissection. Semin Thorac Cardiovasc Surg. 2017;29:150-9.

3. Kim JB, Choo SJ, Kim WK, Kim HJ, Jung SH, Chung CH, et al. Outcomes of acute retrograde type A aortic dissection with an entry tear in descending aorta. Circulation. 2014;130(11 Suppl 1):S39-44. 
4. Nauta FJ, Tolenaar JL, Patel HJ, Appoo JJ, Tsai TT, Desai ND, et al; International Registry of Acute Aortic Dissection (IRAD) Investigators. Impact of retrograde arch extension in acute type B aortic dissection on management and outcomes. Ann Thorac Surg. 2016;102:2036-43.

5. DeAnda A, Volman R, Spiess BD. Repair of type A dissection in a Jehovah's Witness with prior cardiac operation. Ann Thorac Surg. 2009;87: 289-90.
6. Pasic M, Ruisz W, Koster A, Hetzer R. Bloodless surgery of acute type A aortic dissection in a Jehovah's Witness patient. Ann Thorac Surg. 2005;80:1507-10.

7. Ward ST, Khaja MS, Williams DM, Yang B. Staged hybrid approach for an acuteon-chronic aortic dissection with rupture in a Jehovah's Witness patient: case report. J Thorac Cardiovasc Surg. 2015;150:e63-5.

8. Faure EM, Canaud L, Marty-Ané C, Alric P. Hybrid aortic arch repair for dissecting aneurysm. J Thorac Cardiovasc Surg. 2016;152:162-8. 